\title{
Habitação de interesse social e as legislações municipais da região metropolitana de Campinas
}

\author{
Social housing and the municipal laws from campinas \\ metropolitan region
}

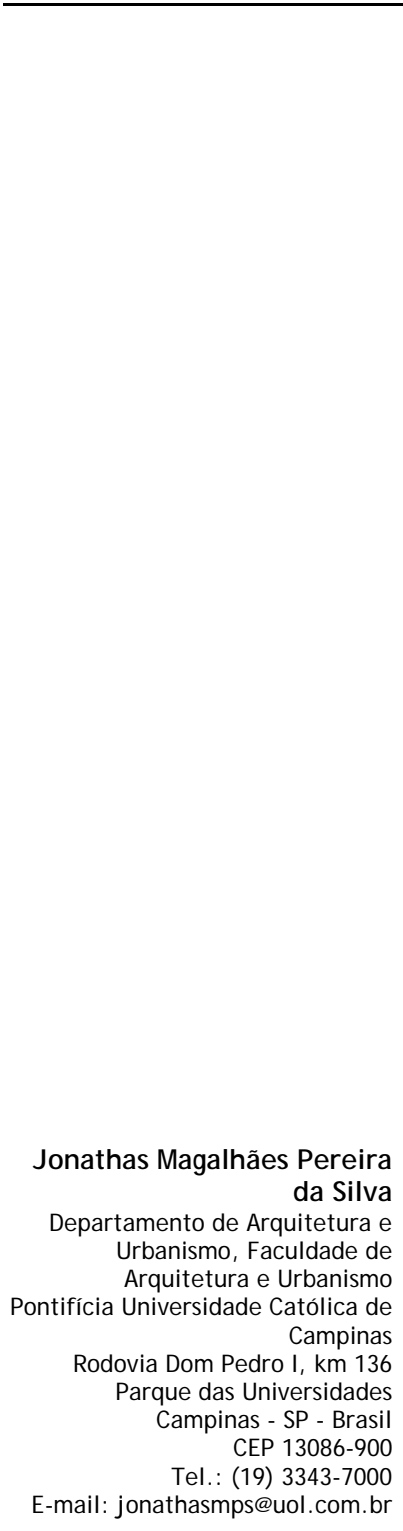

\section{J onathas Magalhães Pereira da Silva}

Resumo complementar que tratasse do parcelamento, uso e ocupação do solo dos municípios, assim como de seus Planos Habitacionais,. No total, foram analisados de mais de cinquenta leis e planos. $\mathrm{O}$ artigo apresenta a fragilidade da legislação urbanística ao lidar com os instrumentos urbanísticos previstos pelo Estatuto da Cidade e que deveriam, ao menos sob o ponto de vista jurídico, atuar na efetivação do princípio constitucional da função social da propriedade. Adotou-se um método comparativo entre municípios possibilitando a identificação da forma como foram tratadas as questões relativas ao macrozoneamento, gestão, parcelamento, sistema de espaços livres, habitação de interesse social e instrumentos urbanísticos, de modo a inferir o quanto o referido princípio constitucional foi incorporado nas legislações municipais. Os resultados obtidos colaboram na compreensão de entraves encontrados no atendimento às demandas de Habitação de Interesse Social, assim como, na elaboração de ações concretas que visem a qualificação do Sistema de Espaços Livres de edificação.

Palavras-chave: Planejamento e gestão do território. Legislação urbanística. Habitação de interesse social. Sistema de espaços livres. Instrumentos urbanísticos.

\begin{abstract}
This article is the result of the analysis of Participatory Master Plans developed between 2001 and 2008 by the local authorities from the Metropolitan Area of Campinas. Throughout the analysis of the Master Plans, it seemed appropriate to include the cities' complementary legislation on land parcelling, use and occupancy, as well as their Housing Plans. Altogether, more than fifty documents were analysed, including laws and plans. The study indicated the fragility of urban legislation in dealing with the urban instruments set out in the Statute of the City, which should, at least from a legal point of view, enforce the constitutional principle of the property social role. A comparative method between municipalities was adopted, in order to identify how they have handled issues related to macrozoning, management, subdivision, open space system, social housing and urban instruments, thus inferring how much the existing constitutional principle was incorporated in the cities' leqislation. The results help to understand the hindrances found for the fulfilment of social interest housing demands, as well as to design actions to improve open urban space systems.
\end{abstract}

Recebido em 09/03/11 Aceito em 08/08/11
Keywords: Urban planning. Urban management. Urban legislation. Housing. Open space system. Urban regulation tools. 


\section{Introdução}

A legislação é formada por diferentes interesses e é resultado de uma composição de forças. Entretanto, considerando certas características historicamente construídas pela sociedade brasileira, como poder econômico concentrado na mão de poucos, forte tradição hierárquica e grandes desigualdades sociais, a legislação resultante tenderá a favorecer os grupos hegemônicos (CHAUI, 2001; MARICATO, 1996; VILLAÇA, 1998; HARVEY, 2005; LEFEBVRE, 1999).

Portanto, uma análise da legislação municipal está muito longe de espelhar a realidade da cidade (VILLAÇA, 2005; MARICATO, 2001a, 2001b). A legislação pode, nessas circunstâncias, escamotear conflitos, aparentemente resolvidos no texto da lei, mas distantes de qualquer solução real.

Qual seria, então, o interesse em estudar as legislações municipais? Qual seria a contribuição deste estudo para a compreensão das questões referentes à habitação de interesse social?

Para responder a essas perguntas, precisaremos considerar que, com a Constituição de 1988 (BRASIL, 1995) e o Estatuto da Cidade, de 2001 (BRASIL, 2001), nasce um novo modelo de gestão nas cidades, em que a participação de diferentes setores da sociedade é idealizada, na busca de se alterar o direito individual, referente à propriedade do solo urbano (BRASIL, 2001). Surge, em nossa constituição, o conceito de "função social da propriedade", criam-se instrumentos urbanísticos para efetivar esse direito difuso e estabelece-se que o plano diretor, desenvolvido de forma participativa, gerará ações concretas utilizando os instrumentos que finalmente conseguiriam promover a tal "função social da propriedade". Isso significa que, do ponto de vista jurídico, a cidade só tem sua função social garantida com o desenvolvimento do plano diretor municipal. Em outras palavras, o referido princípio constitucional ficou refém do desenvolvimento do plano diretor (ALFONSIN, 2008).

Portanto, apesar de entendermos a limitação que um plano diretor tem em promover transformações sociais, de estarmos cientes da limitada participação dos setores sociais no processo de elaboração de um plano e considerarmos que o poder político muitas vezes está a serviço do poder econômico (SCHWARZ, 2005; SILVA, 2007), ainda assim interessa debruçarmo-nos sobre o texto da lei para identificar como foi interpretado e incorporado o novo conceito da "função social da propriedade" em ações práticas que utilizam os novos instrumentos urbanísticos e os novos modelos de gestão administrativa e territorial (SILVA, 2008).

Apesar de o recorte territorial estudado ser uma região metropolitana, composta de 19 municípios Região Metropolitana de Campinas -, não se pretende compreender esse território como uma unidade, portanto a leitura de seu território foi construída por meio da análise das questões urbanísticas municipais.

Cabe considerar que existem muitas experiências internacionais relativas ao planejamento e gestão de regiões metropolitanas, entretanto os diferentes contextos geográficos, políticos, culturais, econômicos e urbanos induzem a diferentes encaminhamentos. Por exemplo, se por um lado Montreal já experimentou, sobre seu território, diferentes recortes e formas de gestão (GILBERT; STEVENSON, 2001), por outro as experiências canadenses pouco se assemelham ao contexto metropolitano de Nairóbi (OMWENGA, 2010), ou ainda ao histórico de formação das regiões metropolitanas da Austrália, onde Sydney, Melbourne, Brisbane, Perth e Adelaide são governadas por um único ente governamental, que se aproxima dos governos estaduais brasileiros (DAWKIN, 2010). Existem ainda interessantes estudos de variação do valor do solo correlacionado ao tipo de gestão metropolitana (ENGELKE; JURI, 2007) que nos servem para compreender outros métodos de trabalho. Entretanto, se consideradas as distintas dinâmicas e pressões econômicas, um pesquisador mais atento, inserido em outro contexto, perceberá a ineficiência das simples transposições de métodos.

Portanto, cabe alertar o leitor para o fato de se ter privilegiado os referenciais bibliográficos brasileiros, uma vez que o presente artigo é fruto da análise comparativa entre legislações urbanísticas de municípios brasileiros, que objetiva identificar o quanto o novo princípio constitucional - função social da propriedade - de fato está incorporado nessas leis. Entende-se que as referências internacionais de planejamento urbano, municipal ou regional, podem vir a contribuir em outra fase da pesquisa, quando esta comparar práticas entre diferentes nações.

O presente texto dialoga com os instrumentos e as práticas por meio da análise das ações concretas, estabelecidas nos planos diretores das cidades analisadas, que intervenham sobre o atendimento do déficit habitacional e sobre a qualificação do sistema de espaços livres de edificação. Busca-se identificar práticas da gestão urbana que 
promovam as políticas públicas habitacionais e a qualificação do sistema de espaços livres.

Entende-se por sistema de espaços livres de edificação todo o espaço não edificado da cidade, ou seja, as ruas, calçadas, praças, largos, parques, quintais, lotes sem edificação, áreas de preservação permanente consolidadas, etc. (MAGNOLI, 2006; RÊGO et al., 2008). Utiliza-se a palavra "sistema" para explicitar a existência de inter-relações (dependência, complementaridade, conectividade, etc.) entre os vários tipos de espaços livres de edificação que se encontram presentes nas cidades (COELHO, 2008; FORMAN, 1997). Chamamos de qualificação do sistema quando seus componentes deslocam ${ }^{1}$ suas relações (HALL, 2006) em benefício do bem-estar social e ambiental.

O planejamento historicamente atuou somente sobre a cidade oficial, isto é, apenas sobre aquele território urbano reconhecido pelo poder público. Simultaneamente, desconsiderou a produção da cidade não oficial, resultante da criação de alternativas inadequadas de moradias, como favelas, cortiços, loteamentos irregulares (ROLNIK, 1997; MARICATO, 1996; BUENO, 2007).

Cada cidade brasileira é composta de diferentes realidades urbanas e tem características específicas quanto ao ecossistema, à geomorfologia, ao clima, à cultura e à economia em que estão insertas; entretanto, de uma forma ou de outra, apresentam processos semelhantes, afinal essas áreas urbanizadas estão sobre o mesmo território nacional e pertencem e são regulamentadas pela mesma nação e Estado nacional (SANTOS, 1993).

Com a Constituição de 1988 (BRASIL, 1995) e o Estatuto da Cidade, de 2001 (BRASIL, 2001), a legislação estabeleceu e regulamentou o princípio da função social da propriedade, que, caso implementado, deveria gerar grandes transformações sobre o território. Portanto, não há forma de garantir o direito à cidade a todo cidadão brasileiro sem equacionar os direitos e deveres relacionados à propriedade privada.

Sabe-se que não é por meio das leis que se transforma a sociedade, entretanto sua análise pode dar indícios do grau de mudanças de valores em curso.

Em outras palavras, não se pretende que, com a análise da legislação, se conheça a realidade do

\footnotetext{
${ }^{1}$ Utiliza-se o termo "deslocar" em vez de "transformar". Tratase de influências da leitura da obra de Stuart Hall, que questiona o processo de "transformação social" como um avanço contínuo. 0 termo utilizado pelo autor propõe um entendimento das alterações de valores socioculturais como sendo fruto de "deslocamentos" de valores socialmente construídos.
}

município, uma vez que aquela não espelha a realidade. Entretanto, entendemos que o processo de construção e aplicação da lei estabelece uma relação dialética em que o confronto entre ideal e real se explicita por meio das contradições. Portanto, ao analisar a legislação de forma comparativa entre municípios de uma mesma região metropolitana, espera-se identificar diferentes graus de possibilidade jurídica na implementação da função social da cidade e da propriedade.

A possibilidade jurídica de intervenção não estabelece necessariamente uma transformação na sociedade. Conhecemos leis que não se cumprem, ou que são válidas na prática só para alguns (SCHWARZ, 2005); entretanto, a legislação, por ser uma construção social, carrega conceitos que paulatinamente são incorporados pelas práticas e valores sociais. Dessa forma, pretende-se identificar as possibilidades que a legislação analisada estabelece na promoção de uma equidade social. Toma-se o direito à moradia e a qualificação dos sistemas de espaços livres para identificar posturas conflitantes e complementares.

\section{Metodologia}

A pesquisa teve como recorte territorial os municípios que compõem a Região Metropolitana de Campinas, uma das três regiões metropolitanas do estado de São Paulo, onde estão também presentes a Região Metropolitana de São Paulo e a Região Metropolitana da Baixada Santista. Segundo os autores Queiroga e Benfatti (2007), o que ocorre no estado de São Paulo é um fenômeno denominado por eles de megalopolização do Sudeste, que se estende pelo eixo "Rio-São Paulo", parte do Sul de Minas, e avança pelas principais rodovias paulistas que conectam São Paulo e Campinas a Ribeirão Preto, a São Carlos, a Sorocaba, a São José dos Campos, para citar apenas os principais centros regionais já claramente integrados no processo.

É nesse contexto que se encontra a Região Metropolitana de Campinas, que foi formada em 2000 - Lei Complementar no 870 (SÃO PAULO, 2000) - e é constituída pelos municípios de Americana, Artur Nogueira, Campinas, Cosmópolis, Engenheiro Coelho, Holambra, Hortolândia, Indaiatuba, Itatiba, Jaguariúna, Monte Mor, Nova Odessa, Paulínia, Pedreira, Santa Bárbara D’Oeste, Santo Antônio de Posse, Sumaré, Valinhos e Vinhedo.

As argumentações do presente artigo baseiam-se na análise dos planos diretores que foram desenvolvidos entre 2001 e 2008, portanto após a Lei $n^{0} 10.257$, de 10 de julho de 2001, conhecida 
como Estatuto da Cidade (BRASIL, 2001). Foram também analisadas as legislações de parcelamento, uso e ocupação de solo decorrentes ou não dos planos diretores, portanto em alguns $\operatorname{casos}^{2}$ essas legislações são anteriores ao Estatuto da Cidade, mas se encontram em vigor com ou sem revisões pontuais.

Na busca de uma síntese construiu-se um quadro que mapeia as ações e posturas delineadas nas legislações urbanísticas estudadas, de modo a inferir o quanto o princípio da função social da propriedade está incorporado nas legislações municipais. A presença do princípio legal pode ser percebido na incorporação dos instrumentos urbanísticos, como no caso das delimitações das Zonas Especiais de Interesse Social (Zeis), para atender às demandas por habitação de interesse social. Procurou-se também destacar o estabelecimento de ações concretas na qualificação do Sistema de Espaços Livres.

No total foram mais de 50 documentos legislativos analisados. Apresentam-se a seguir os principais planos, leis e decretos de cada município analisados pela pesquisa realizada em 2009.

(a) Americana: Lei $n^{\circ}$ 4.597/08 (SÃO PAULO, 2008a), Lei no 4.676/08 (SÃO PAULO, 2008b) e Plano Habitacional (SÃO PAULO, 2002).

(b) Campinas: Lei $\mathrm{n}^{\circ}$ 004/96 (CAMPINAS, 1996), Lei $n^{\circ} 11.621 / 03$ (CAMPINAS, 2003); Lei $\mathrm{n}^{\circ}$ 15/06 (CAMPINAS, 2006); Decreto $\mathrm{n}^{\circ}$ 16.390/08 (CAMPINAS, 2008); Lei no 26/09 (CAMPINAS, 2009a); Lei $n^{\circ}$ 28/09 (CAMPINAS, 2009b).

(c) Artur Nogueira: Lei $n^{\circ}$ 441/07 (ARTUR NOGUEIRA, 2007); Lei $n^{\circ} 337 / 03$ (ARTUR NOGUEIRA, 2003).

(d) Cosmópolis: Lei n ${ }^{\circ}$ 2.949/07 (COSMÓPOLIS, 2007); Lei $n^{\circ}$ 3.129/09 (COSMÓPOLIS, 2009); Lei $\mathrm{n}^{\circ}$ 2.812/05 (COSMÓPOLIS, 2005).

(e) Holambra: Anteprojeto de Lei do Plano Diretor de Maio de 2006 (HOLAMBRA, 2006) e de dezembro de 2008 (HOLAMBRA, 2008).

(f) Hortolândia: Lei no 2.092/08 (HORTOLÂNDIA, 2008); Lei n ${ }^{\circ}$ 1.905/07 (HORTOLÂNDIA, 2007a); Anteprojeto de Lei $n^{\circ}$ 160/06 (HORTOLÂNDIA, 2006); e 137/07 (HORTOLÂNDIA, 2007b); Plano Habitacional (HORTOLÂNDIA, 2005).

\footnotetext{
${ }^{2}$ Refere-se a: a) Lei ${ }^{0} 3.525$, de 18 de março de 1998, que dispõe sobre loteamentos, arruamentos, retalhamentos de imóveis em geral, e dá outras providências no município de Indaiatuba; b) Lei $n^{0} 674$, de 30 de junho de 1978, que objetiva reger todo e qualquer loteamento, arruamento e desmembramento de terreno no Município de Nova Odessa, obedecidas as normas federais e estaduais relativas à matéria (Atualizada pelas Leis no 1.916/ 03 e no 822/ 82).
}

(g) Indaiatuba: Lei $\mathrm{n}^{\circ}$ 4.067/01 (INDAIATUBA, 2001a); Lei $n^{\circ}$ 4.594/04 (INDAIATUBA, 2004); Lei $^{\circ}$ 4.066/01 (INDAIATUBA, 2001b); Lei $n^{\circ}$ 3.525/98 (INDAIATUBA, 1998).

(h) Itatiba: Lei $n^{\circ}$ 3.759/04 (ITATIBA, 2004a); Lei $n^{\circ} 3.761 / 04$ (ITATIBA, 2004b); Lei $n^{\circ}$ 3.765/04 (ITATIBA, 2004c).

(i) Jaguariúna: Lei n ${ }^{\circ}$ 96/04 (JAGUARIÚNA, 2004a); Lei no 97/04 (JAGUARIÚNA, 2004b);.Lei $n^{\circ}$ 126/07 (JAGUARIÚNA, 2007).

(j) Monte Mor: Lei $\mathrm{n}^{\circ}$ 0001/06 (MONTE MOR, 2006a); Lei no 0002/06 (MONTE MOR, 2006b); Lei $n^{\circ}$ 11/07 (MONTE MOR, 2007).

(k) Nova Odessa: Lei no 10/06 (NOVA ODESSA, 2006); Lei ${ }^{\circ}$ 0674/78 (NOVA ODESSA, 1978).

(l) Paulínia: Lei no 2.852/06 (PAULÍNIA, 2006); Lei $n^{\circ}$ 39/08 (PAULÍNIA, 2008); Lei $n^{\circ} 2.668 / 03$ (PAULÍNIA, 2003); Decreto n ${ }^{\circ} 5.541 / 07$ (PAULÍNIA, 2007).

(m) Pedreira: Lei n 2.792/08 (PEDREIRA, 2008).

(n) Santa Barbara D’Oeste: Lei n ${ }^{\circ}$ 028/06 (SANTA BARBARA D’OESTE, 2006).

(o) Santo Antônio de Posse: Lei n ${ }^{\circ}$ 017/06 (SANTO ANTÔNIO DE POSSE, 2006).

(p) Sumaré: Lei no 4.250/06 (SUMARÉ, 2006); Lei no 2.831/95 (SUMARÉ, 1995); Lei no 4.759/08 (SUMARÉ, 2008a); Lei no 4.760/08 (SUMARÉ, 2008b); Lei no 4.880/09 (SUMARÉ, 2009).

(q) Valinhos: Lei $n^{0} 3.841 / 04$ (VALINHOS, 2004); Lei ${ }^{\circ} 4.186 / 07$ (VALINHOS, 2007).

(r) Vinhedo: Lei n ${ }^{\circ}$ 66/07 (VINHEDO, 2007).

Os dados necessários para o desenvolvimento do presente trabalho foram levantados por diferentes procedimentos:

(a) os dados dos municípios de Americana, Campinas, Valinhos e Vinhedo foram levantados por meio da internet, nas páginas oficiais das prefeituras (Executivo);

(b) os dados de Jaguariúna e Sumaré foram levantados por meio da internet, nas páginas oficiais das câmaras de vereadores (Legislativo);

(c) os dados de Indaiatuba e Itatiba foram levantados por meio da internet, nos serviços jurídicos que disponibilizam legislação de diferentes municípios (Judiciário); e

(d) os dados dos municípios de Cosmópolis, Santo Antônio de Posse, Santa Bárbara D’Oeste, Engenheiro Coelho, ${ }^{3}$ Artur Nogueira, Monte Mor,

${ }^{3}$ A comissão do plano diretor da prefeitura de Engenheiro Coelho, na ocasião da pesquisa (2009), ainda não havia concluído 
Nova Odessa, Paulínia, Pedreira, Holambra e Hortolândia foram obtidos por meio de contato direto com as prefeituras.

Apesar de os anexos dos planos diretores serem parte integrante da lei, há normalmente dificuldade em obtê-los. É comum o Executivo ou a Câmara disponibilizarem o texto da lei do plano diretor, principalmente quando ocorre continuidade na gestão que foi protagonista de sua concepção, entretanto, para a obtenção dos anexos (textos, descrições, mapas e tabelas), foi necessário contato direto com a maioria dos municípios estudados.

Procurou-se, num primeiro momento, identificar, por meio de leitura, os artigos das leis analisadas que possibilitassem o confronto entre as diferentes formas de interpretação e incorporação pela legislação municipal do direito à moradia e da qualificação dos sistemas de espaços livres. Depois de identificados os artigos relevantes ao foco da pesquisa, eles foram reorganizados em um novo documento, segundo os seguintes temas $\mathrm{e}$ interesses específicos:

(a) macrozoneamento: por proporcionar a compreensão das diretrizes estabelecidas para todo o território municipal;

(b) gestão: visando ao entendimento das características e dos papéis dos conselhos municipais, assim como dos instrumentos de monitoramento adotados;

(c) parcelamento: para identificar os parâmetros de doação de áreas públicas adotadas pelo município e esclarecer as especificidades adotadas nas áreas destinadas à habitação de interesse social;

(d) habitação de interesse social: para identificar como e o quanto o tema foi tratado pela legislação;

(e) Sistema de Espaços Livres: para identificar ações concretas e o estabelecimento de conceitos referentes a seus elementos; e

(f) instrumentos urbanísticos: para identificar quais instrumentos urbanísticos, regulamentados pelo estatuto da cidade, foram considerados e incorporados pela legislação.

Após esse processo de análise e sistematização das informações, passou-se para a construção de quadros-síntese que explicitassem os pontos comuns e as diferenças encontradas.

o anteproj eto de lei do que seria seu primeiro plano diretor portanto não foi possível incluir esse município na análise.

\section{Análise e resultados obtidos}

O procedimento de análise promove uma comparação entre municípios, buscando destacar os temas já mencionados.

\section{Macrozona}

No tema do macrozoneamento identificou-se como o termo e respectivo conceito foram incorporados no desenvolvimento do plano diretor. O interesse neste item está em identificar se os planos diretores conseguiram refletir no texto da lei um olhar sobre todo o território municipal, e não apenas nas áreas de ocupação urbana.

Dos 19 municípios da Região Metropolitana de Campinas, apenas nove, isto é, menos de 50\% deles, utilizam o macrozoneamento em seu planejamento. Dos dez municípios que não têm macrozonas definidas, quatro deles parecem confundir o conceito de macrozoneamento com o de zoneamento urbano ${ }^{4}$ (Figuras 1 e 2).

Essa confusão conceitual ocorreu apesar dos esforços do Ministério das Cidades, que teve um intenso programa, em $2004,{ }^{5}$ na capacitação de técnicos envolvidos no planejamento das cidades, além das edições de publicações na forma de cartilhas, nas quais se sugeriam procedimentos e se explicitaram os conceitos.

\section{Gestão Urbana}

No tema gestão urbana identificou-se como o modelo participativo de planejamento se concretiza no texto da lei. Entende-se que a possibilidade de controle social na implementação do plano diretor está apoiada nos instrumentos, modelos, práticas e procedimentos que permitem a aproximação e intervenção da sociedade organizada nas políticas públicas.

A Figura 3 nos mostra que todos os municípios que desenvolveram plano diretor estabeleceram conselhos. Deve-se considerar que, apesar de existir o Conselho no texto da lei, não significa que ele tenha sido de fato implementado. Entretanto, o fato de todos criarem Conselhos mostra que, de alguma forma, estava clara a necessidade, perante a lei, da criação de Conselho. Vários estudos sobre planos diretores alertam para

\footnotetext{
${ }^{4}$ Enquanto o Zoneamento urbano está restrito a área urbana e procura estabelecer as densidades e formas de uso e ocupação segundo as infraestruturas instaladas, o Macrozoneamento lida com diretrizes sobre todo o território municipal, seja ele urbano ou rural, identificando características, tendências ou papeis de um determinado recorte territorial

${ }^{5}$ Com exceção de Indaiatuba, que teve seu plano diretor aprovado em 2001, todos os outros municípios tiveram os planos diretores aprovados a partir de 2004.
} 
a fragilidade dos processos participativos (BUENO, 2007; SILVA, 2007; VILLAÇA, 2005). O quadro-síntese reforça essa tese. Temos uma participação institucionalizada, mas que não garante a inclusão de grupos sociais historicamente excluídos no debate e muito menos serve para garantir direitos.

Na Figura 4 identifica-se que oito municípios (44\%) criam fundos específicos para a habitação, e apenas três municípios não criam o Fundo de Habitação de Interesse Social nem o Fundo de Desenvolvimento Urbano. Isso pode ser explicado pelos programas federais que exigem a criação de fundo de habitação para que os municípios recebam receitas. Portanto, nesse caso, a criação de fundos é uma ação municipal que pode ser fruto da pressão de outras instâncias de governo. ${ }^{6}$

Dos municípios vizinhos ao município de Campinas apenas Monte Mor, Paulínia e Valinhos não criaram o Fundo de Habitação de Interesse Social (Figura 4).

\section{Sistema de Espaços Livres}

O Sistema de Espaços Livres é um conceito ainda pouco incorporado nas políticas públicas, entretanto foi possível identificar o quanto o plano diretor define diretrizes e ações concretas visando à qualificação dos espaços livres públicos.

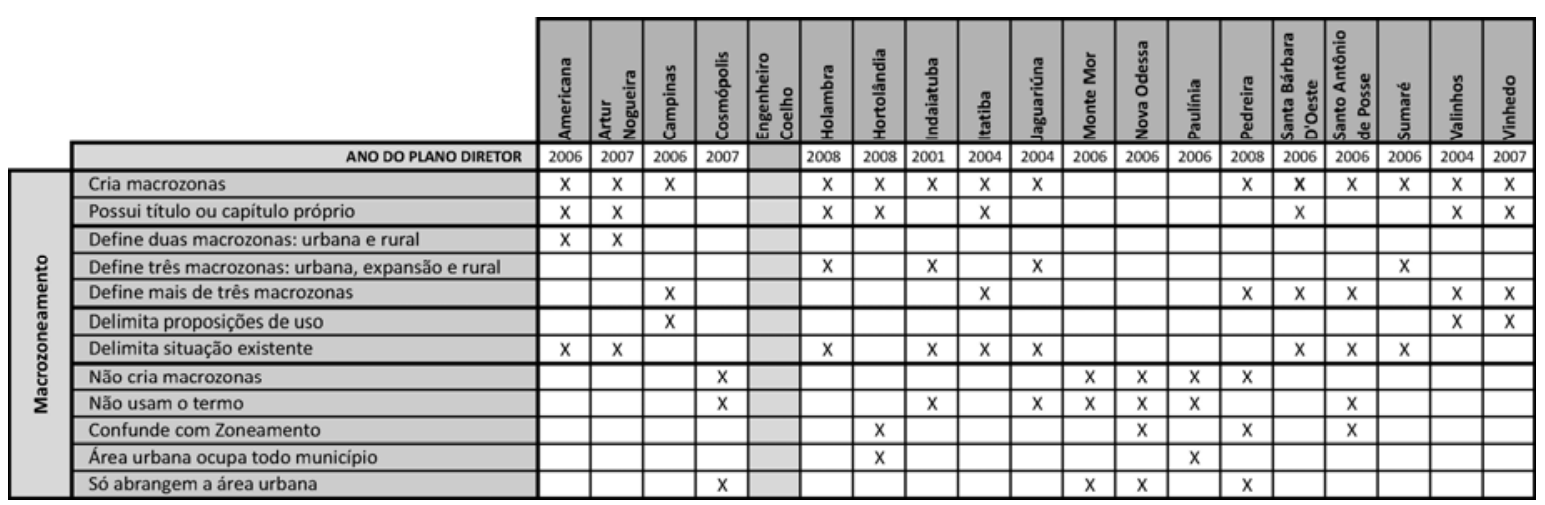

Figura 1 - Características do macrozoneamento dos municípios da RMC

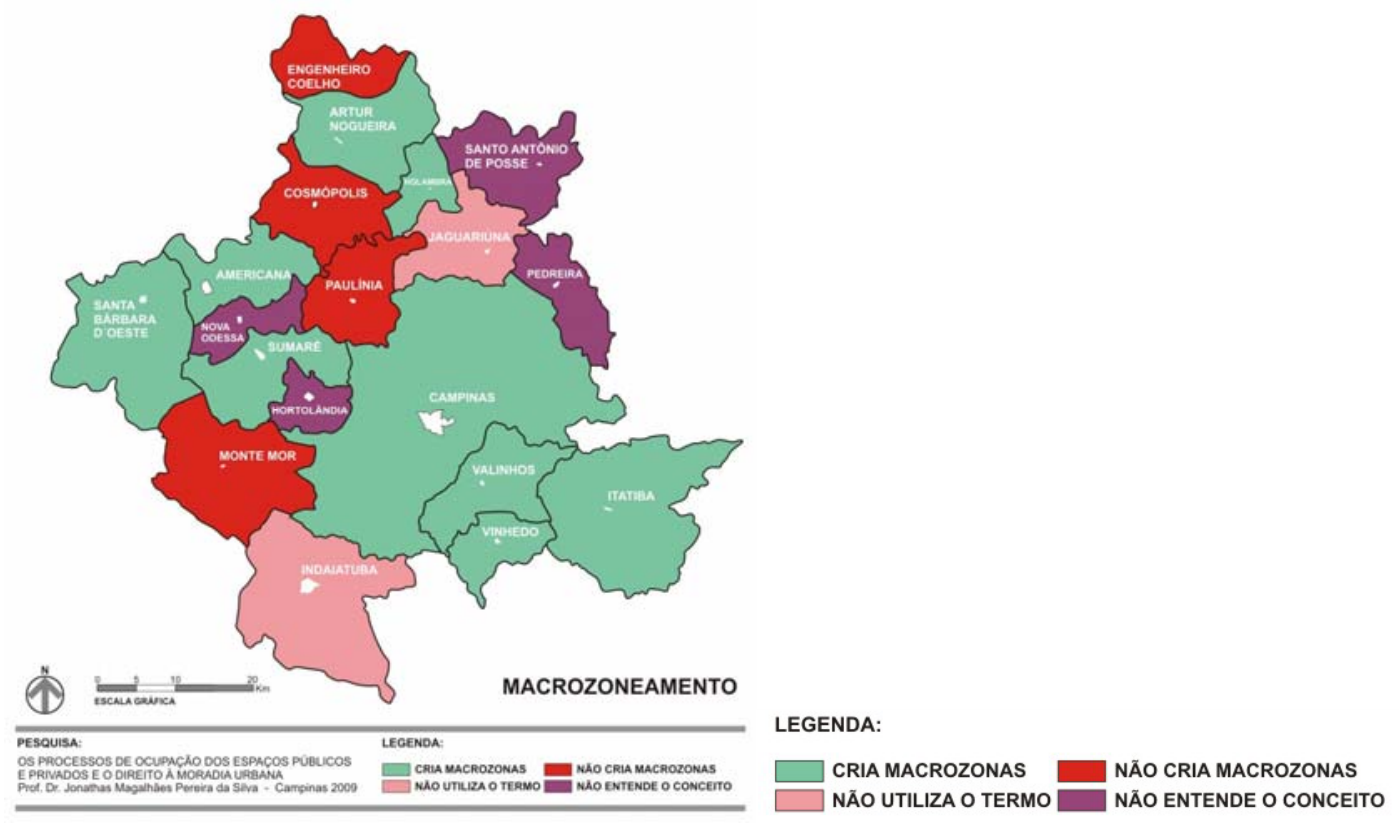

Figura 2 - Espacialização da situação do macrozoneamento na RMC 


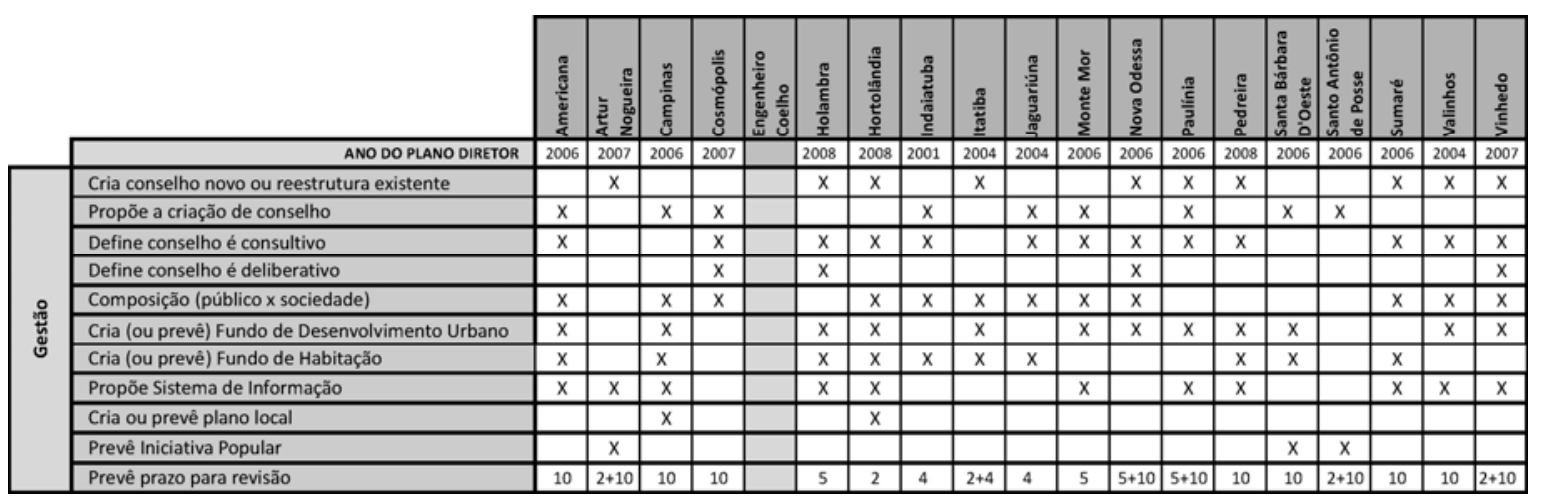

Figura 3 - Caracterização do Sistema de Gestão proposto dos Municípios da RMC

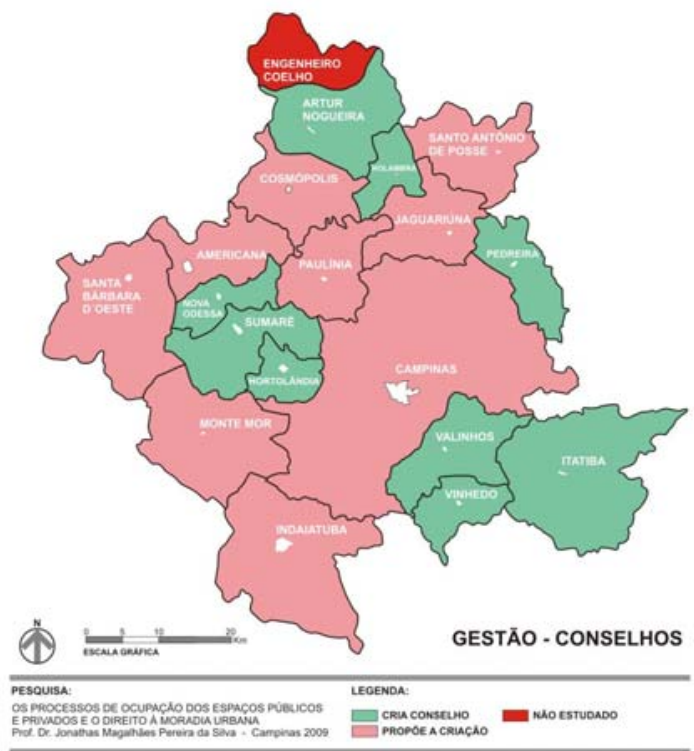

LEGENDA:

$\square$ CRIA CONSELHO
$\square$ PROPŌE A CRIAÇÃO

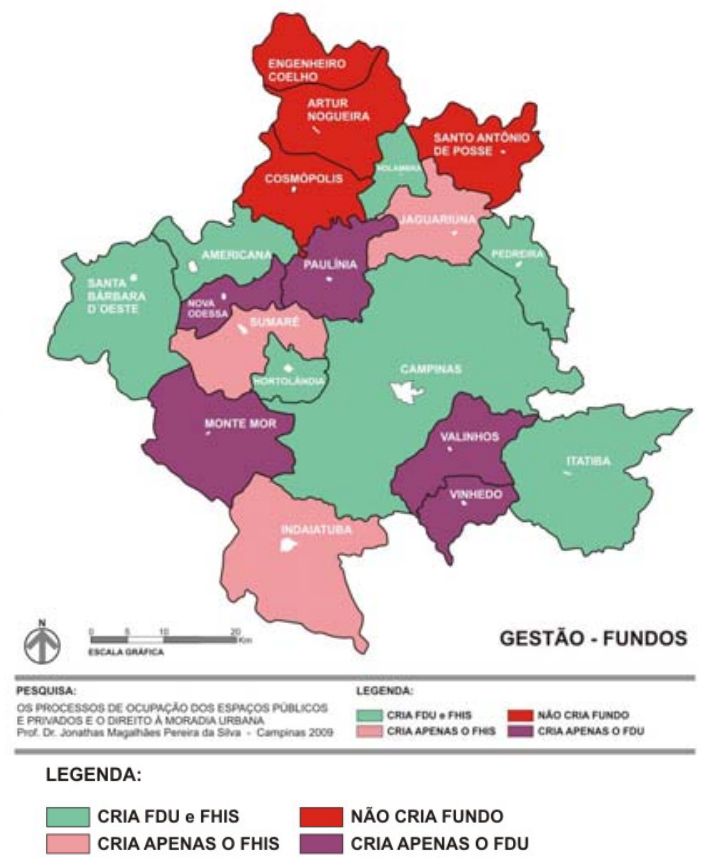

CRIA FDU E FHIS
CRIA APENAS O FHIS
CRIA APENAS O FDU

Figura 4 - Espacialização da situação do Sistema de Gestão Municipal na RMC

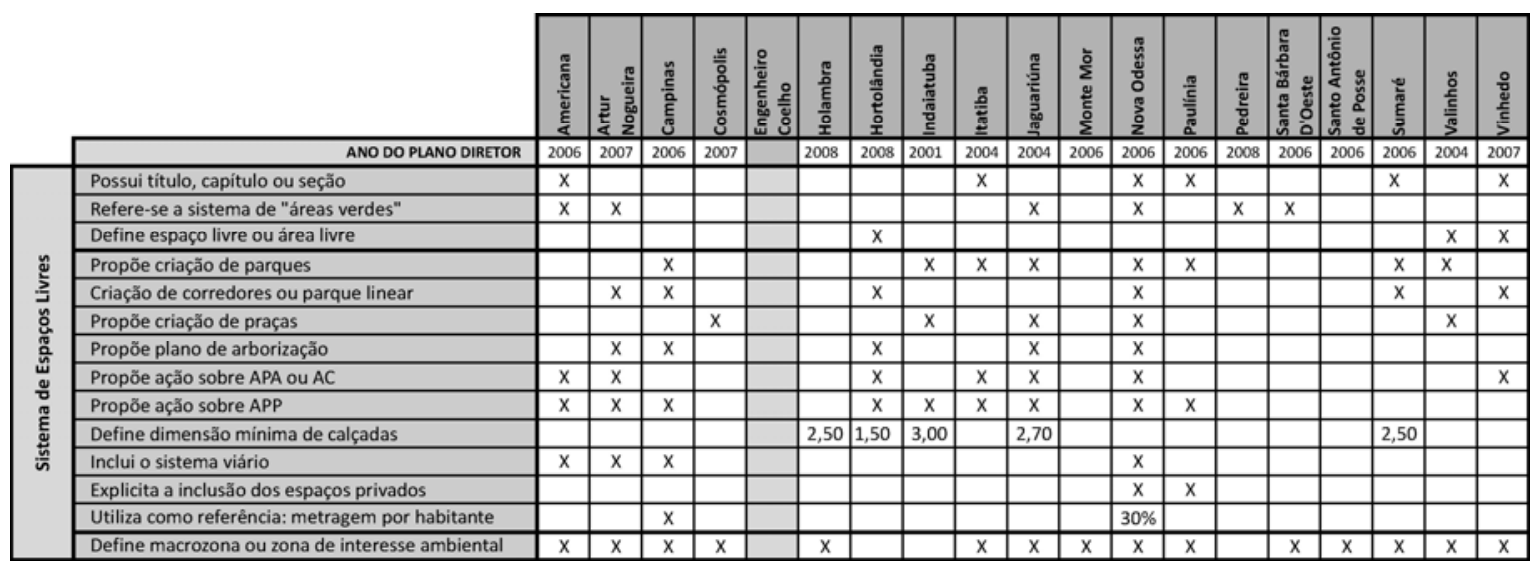

Figura 5 - Caracterização do Sistema de Espaços Livres dos municípios da RMC

Dos municípios analisados, seis (33\%) não se referem ao Sistema de Espaços Livres, nem mesmo propõem ações sobre os espaços livres públicos (Figura 5). Observa-se na Figura 6 que os municípios que não consideram esse tema parecem formar um cinturão quase contínuo, que vai de 
Monte Mor a Pedreira, interrompido apenas por Americana.

Por outro lado, é interessante notar que $44 \%$ dos municípios estudados apresentam propostas concretas, contemplando, na maioria, mais de um item analisado (parques, praças, arborização urbana, preservação de APP e criação de áreas de proteção ou conservação ambiental).

\section{Parcelamento}

Para analisar este item foi necessário ampliar a proposta inicial da pesquisa e incorporar na análise as leis de parcelamento, uso e ocupação do solo. O item se justifica pela pressão existente na região por novos parcelamentos de solo. A revisão da lei de parcelamento 6.766/79, ocorrida em 1999 (BRASIL, 1979), concedeu aos municípios maior autonomia. A análise desse item possibilita identificar diferentes posturas quanto às porcentagens destinadas às áreas institucionais e áreas verdes ou quanto à existência de loteamentos e condomínios fechados. O destaque dado a esse item se mostra pertinente ao considerarmos a atual (2011) tramitação do Projeto de Lei n ${ }^{\circ}$ 3.057/00 (WANDERVAL et al, 2000) (Nova lei de responsabilidade territorial), que amplia e revê a lei de parcelamento (Lei $n^{\circ}$ 6.766/79 e suas atualizações).

Os resultados apontam para um descompasso entre a legislação de parcelamento de solo e os planos diretores. Em uma região metropolitana onde existe uma pressão por ocupação de novas áreas, a legislação de parcelamento deveria acompanhar os novos paradigmas jurídicos incorporados no plano diretor do município.

Observa-se nas Figuras 7 e 8 que o setor sudoeste da Região Metropolitana de Campinas não reviu a lei de parcelamento à luz do plano diretor. Esse mesmo setor possui um crescimento pressionado por população de menor renda, no qual, do ponto de vista jurídico, a pressão pela ocupação do solo ocorre sem considerar os instrumentos urbanísticos do plano diretor.

\section{Habitação}

Buscou-se identificar as diretrizes e ações concretas que visem efetivar o direito à moradia no município. Destacam-se as implementações de Zeis para fins de habitação social, seus conceitos e flexibilizações propostas. $\mathrm{O}$ item se mostra relevante quando, em 2010, se procura implementar o programa federal "Minha Casa, Minha Vida”, sendo um dos grandes questionamentos do programa a falta de critérios para a localização dos novos empreendimentos. Destacaram-se os tipos de Zeis estabelecidas pelos planos.

Encontraram-se dois tipos recorrentes:

(a) Zeis de indução, que trabalham com áreas não ocupadas definidas para implementação de programas habitacionais de interesse social; e

(b) Zeis de regularização, que visam à regularização urbanística e fundiária de áreas ocupadas.

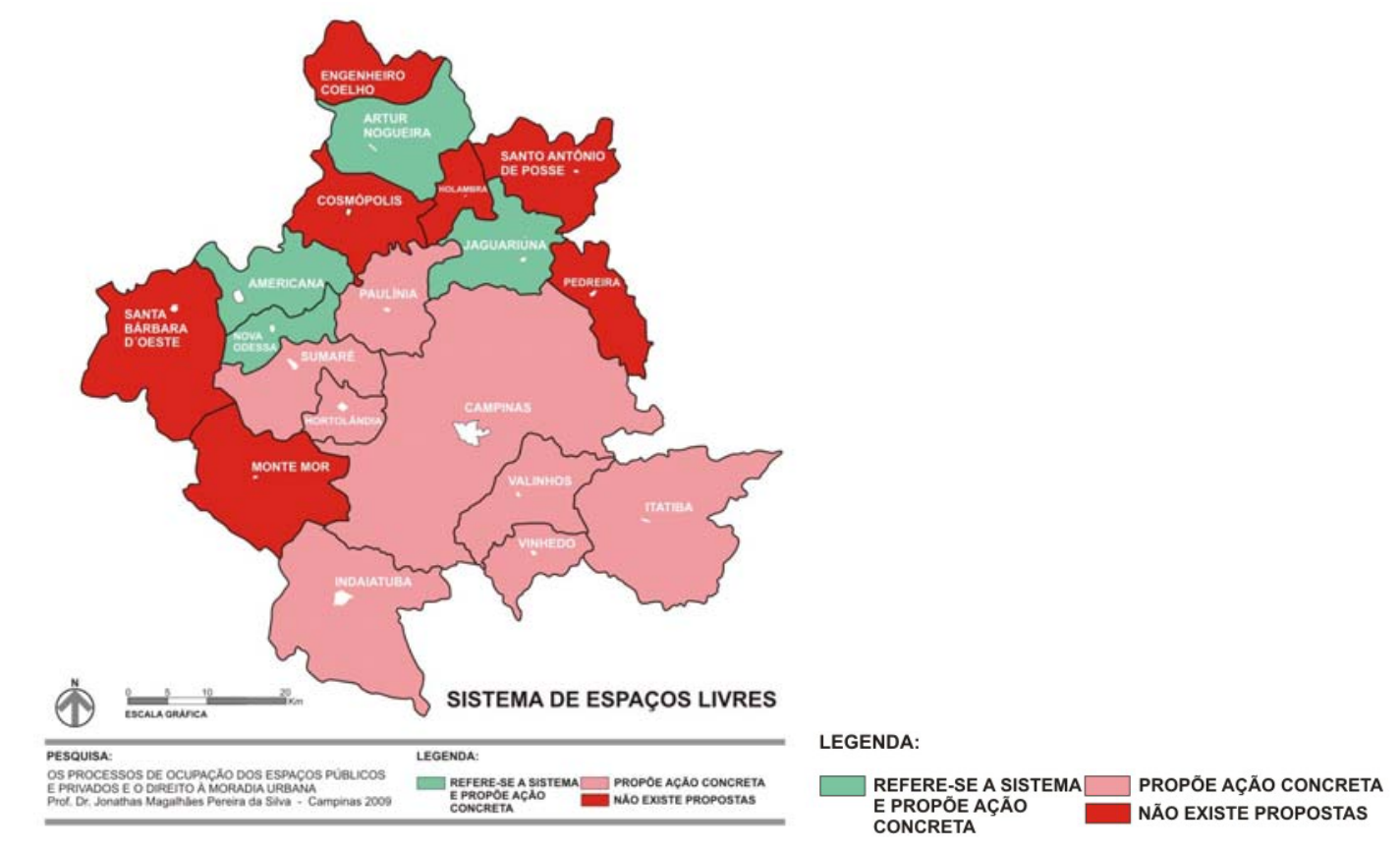

Figura 6 - Espacialização da situação do Sistema de Espaços Livres na RMC 


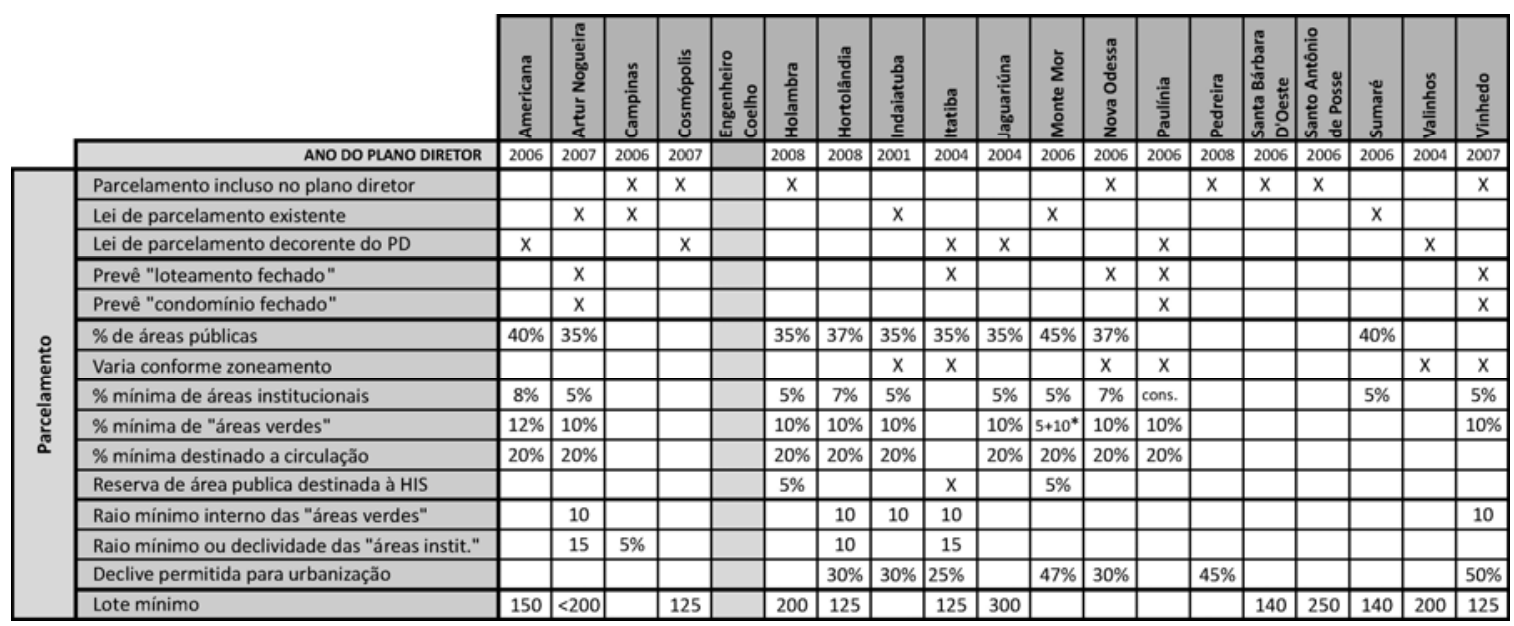

Figura 7 - Caracterização do parcelamento dos municípios da RMC

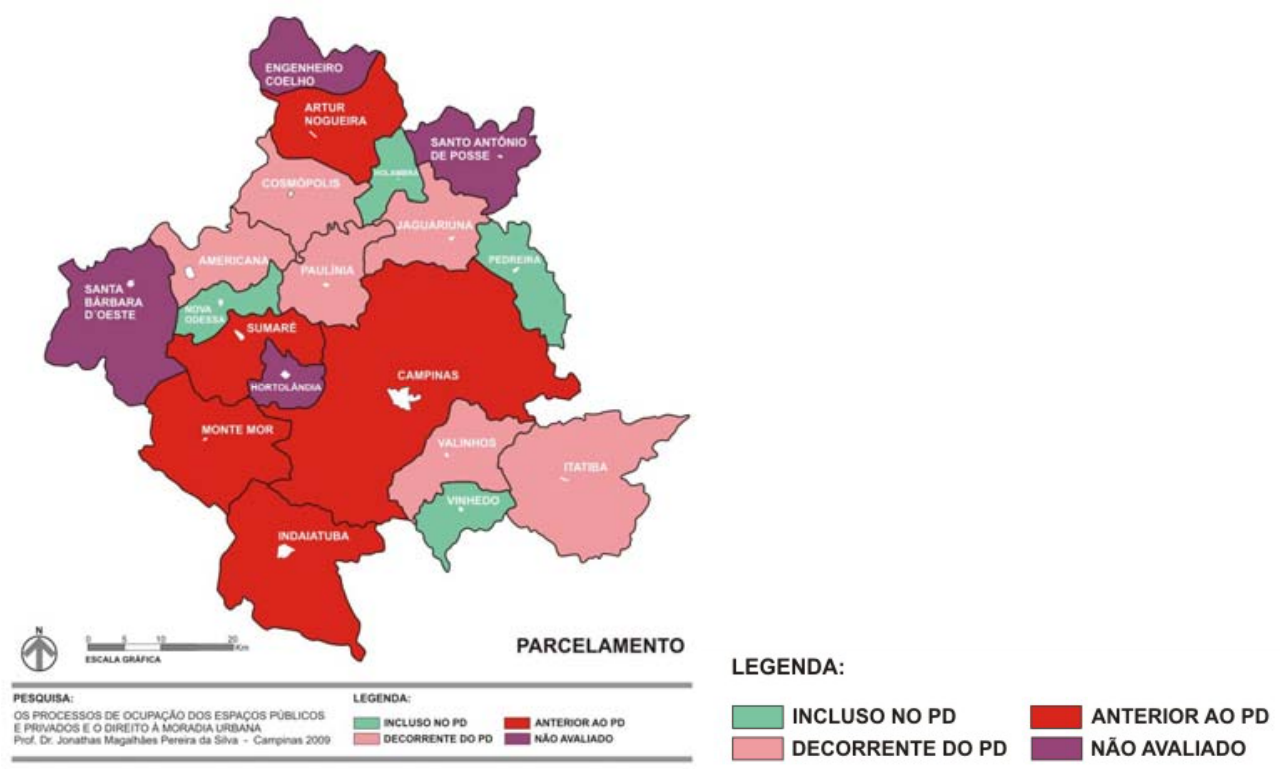

Figura 8 - Espacialização da situação da legislação de Parcelamento na RMC

Foi feita uma análise dos planos municipais de habitação que haviam sido desenvolvidos até aquele momento (2009). Dos 19 municípios da RMC apenas Hortolândia e Americana tinham planos municipais de habitação. Os municípios de Paulínia, Santo Antônio de Posse e Indaiatuba não fazem previsão de Zeis, nem referência à habitação de interesse social no texto da lei. Apesar de Santo Antônio de Posse ter capítulo específico para tratar sobre habitação, a lei não aborda questões relativas à habitação destinada à população de baixa renda. Por fim, o município de Nova Odessa, que ainda não delimitou as Zeis, refere-se a um plano municipal de habitação ainda não desenvolvido na ocasião (Figuras 9 e 10).

\section{Instrumentos Urbanísticos do Estatuto da Cidade}

Procurou-se identificar como estão insertos e como foram apropriados os novos conceitos dos instrumentos urbanísticos contidos no Estatuto da Cidade (BRASIL, 2001). A Constituição de 1988 (BRASIL, 1995) definiu que seria por meio do plano diretor que se implementaria a função social da propriedade e da cidade. Portanto, em tese, o uso dos instrumentos urbanísticos é o que viabiliza, ao menos juridicamente, uma intervenção na propriedade privada visando ao cumprimento de sua função social. Consequentemente, a forma com que os instrumentos urbanísticos são incorporados no texto da lei pode permitir a análise da efetividade jurídica da implementação do conceito da função social da propriedade. 


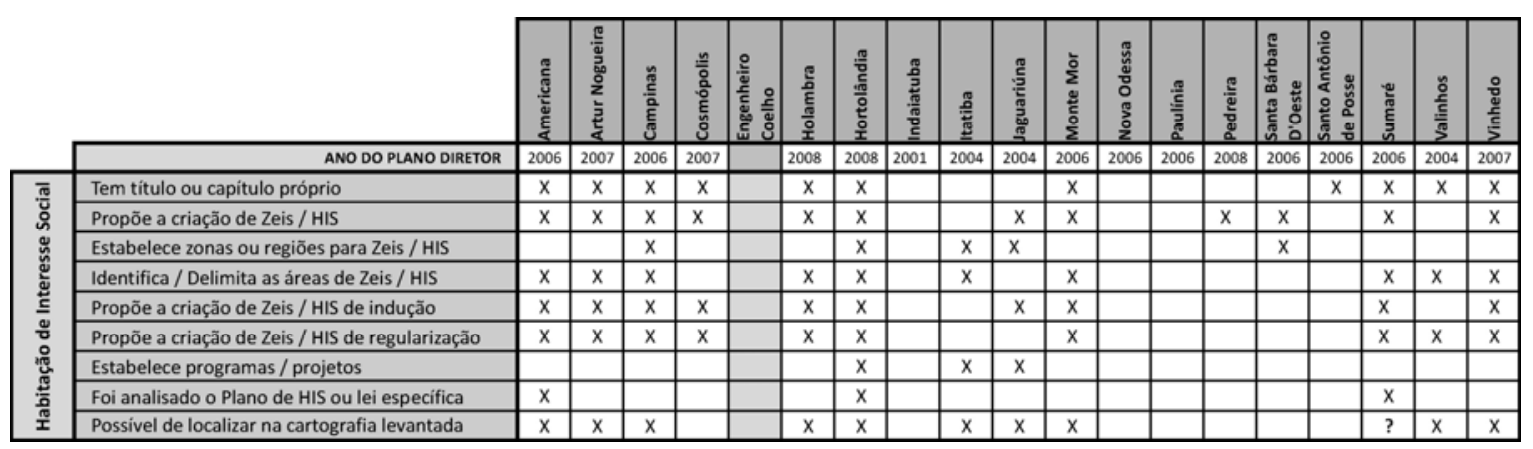

Figura 9 - Caracterização do legislação referente a HIS dos municípios da RMC

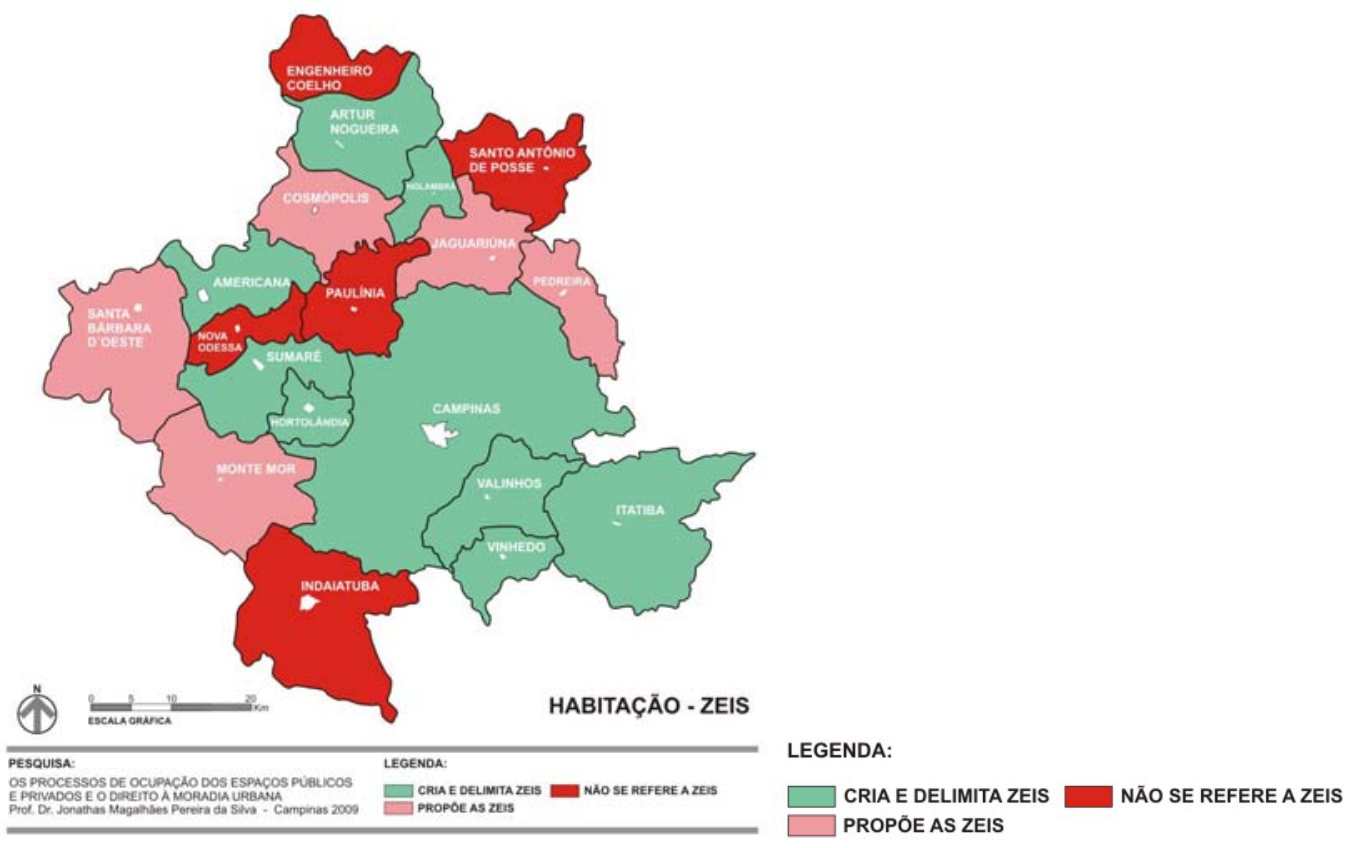

Figura 10 - Espacialização da situação da legislação referente à HIS na RMC

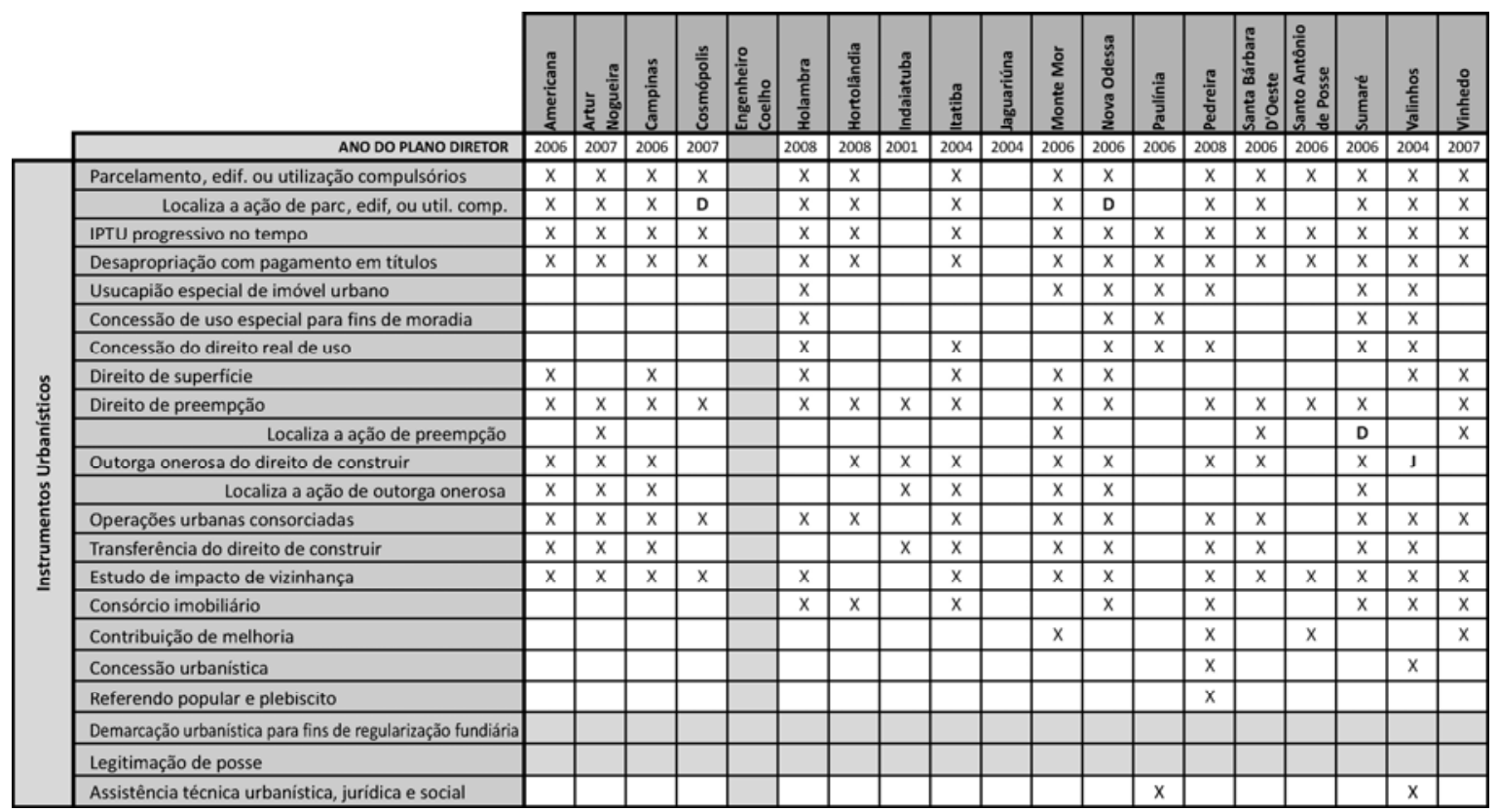

Figura 11 - Caracterização da legislação referente a Instrumentos Urbanísticos dos Municípios da RMC 
Na Figura 12 destaca-se o “cinturão" de municípios em torno do Município de Campinas, que prevê a utilização do usucapião urbano, instrumento urbanístico de regularização fundiária.

Observando conjuntamente as Figuras 10 e 12, nota-se ainda que os municípios de Paulínia e Nova Odessa, apesar de não criar Zeis, adotam instrumentos urbanísticos de usucapião urbano, enquanto os municípios de Americana, Artur Nogueira, Campinas, Cosmópolis, Hortolândia e Vinhedo criam Zeis de regularização, mas não adotam o já citado instrumento urbanístico de regularização. Alguns desses municípios, como Campinas, por exemplo, abordam a questão da regularização fundiária, entretanto a utilização do usucapião urbano não está explícita na lei do plano diretor.

\section{Considerações finais}

Por meio de análise comparativa, adotando-se questionamentos comuns aos municípios estudados, foi possível a construção de seis quadros, que conferem uma visão geral das questões relativas ao macrozoneamento, gestão municipal, Sistema de Espaços Livres, parcelamento, habitação de interesse social e uso dos instrumentos urbanísticos na Região Metropolitana de Campinas.

A partir dos quadros, foi possível gerar mapas que localizassem no espaço metropolitano as questões mapeadas, conferindo uma nova leitura ao material desenvolvido. Ainda por meio da cartografia desenvolvida pelos municípios, construiu-se uma base cartográfica que abrange toda a região metropolitana de Campinas, possibilitando a compreensão das zonas de contato, assim como tendências espaciais que não se restringem aos limites municipais.

O mapa-síntese possibilita identificar a relação espacial entre as áreas de Zeis e a área urbanizável, isto é, circunscrita no perímetro urbano.

A leitura do mapa-síntese (Figura 13) possibilita as seguintes constatações:

(a) a justaposição dos perímetros urbanos municipais possibilita visualizar a continuidade de áreas urbanizáveis resultante da soma das legislações municipais;

(b) existem fragmentos de áreas rurais, localizados entre Paulínia e Campinas, entre Campinas e Monte Mor, e também entre Nova Odessa e Sumaré;

(c) verifica-se a presença da concentração de áreas urbanas já parceladas no eixo de Vinhedo a Santa Barbara D’Oeste, com grandes espaços de uso rural, apesar de a predominância dessas áreas serem circunscritas ao perímetro urbano;

(d) há concentração de Zeis nos setores sul e sudeste, principalmente a sudoeste da Rod. Anhanguera; e

(e) há concentração de Zeis nas áreas de periferia da área urbana já parcelada.

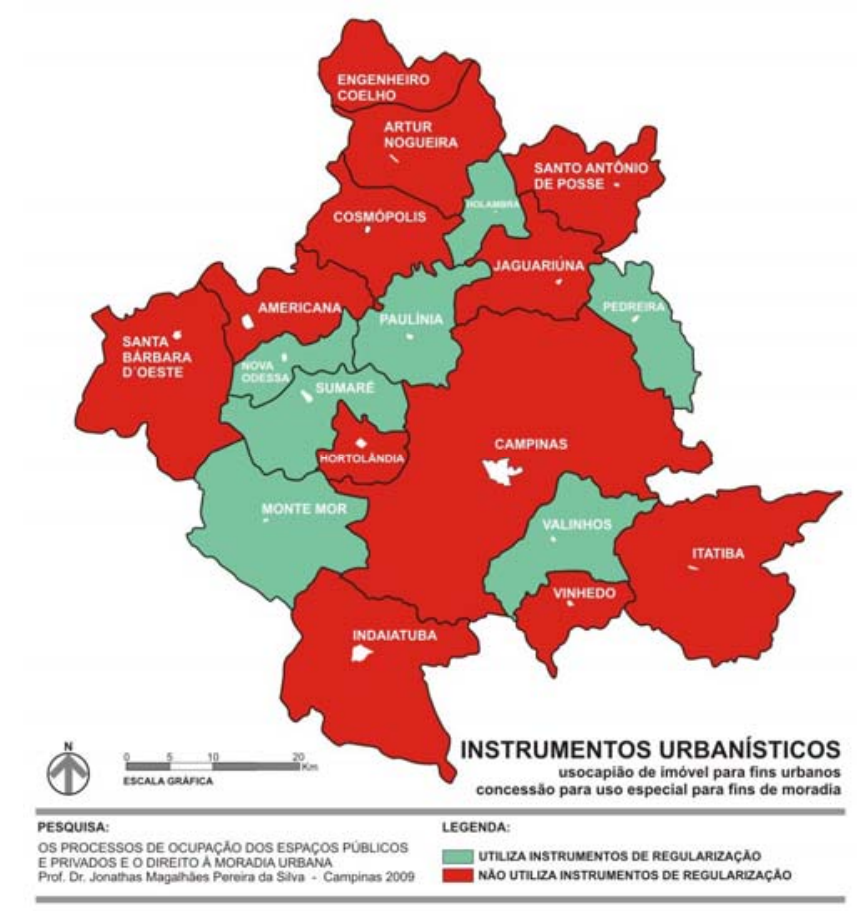

LEGENDA:

Figura 12 - Espacialização da situação da legislação referente aos instrumentos urbanísticos dos municípios na RMC 

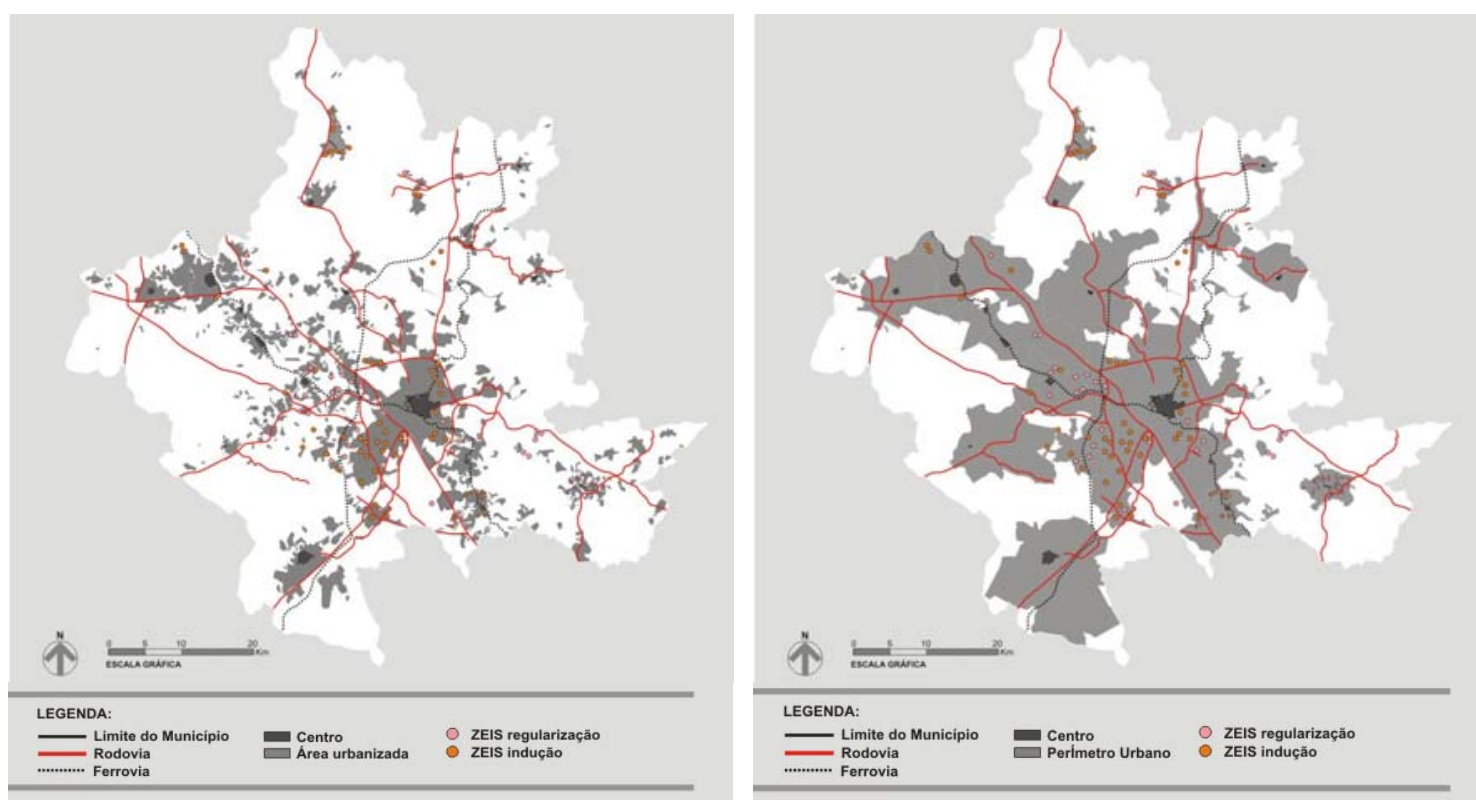

Figura 13 - Mapa-síntese: os círculos localizam as Zeis previstas na RMC

Nota: no mapa à esquerda, a mancha cinza se refere às áreas urbanizadas e no mapa à direita, a mancha cinza, às áreas pertencentes aos perímetros urbanos.

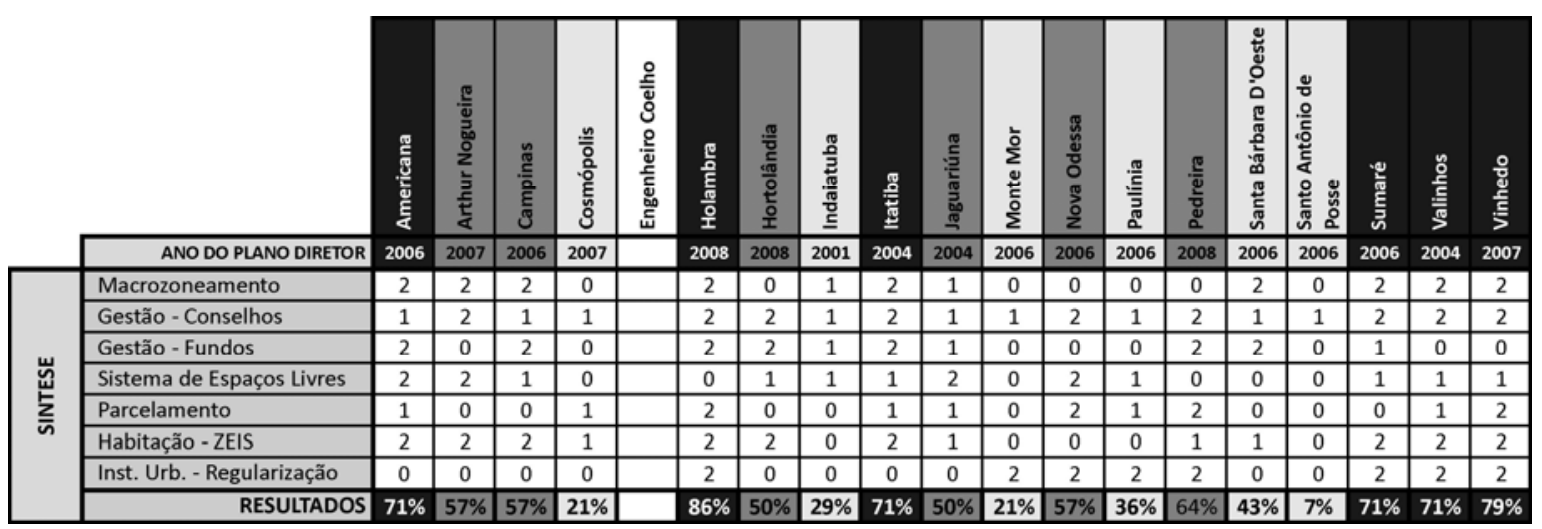

Figura 14 - Quadro comparativo da abrangência jurídica da legislação dos municípios da RMC

Com os dados levantados e sistematizados pelos quadros, sínteses dos temas tratados, procurou-se valorar cada aspecto abordado seguindo os seguintes critérios:

(a) os pontos variam de 0 a 2; e

(b) o município é pontuado com 2 quando atende integralmente ao item analisado, com 1 quando atende parcialmente, e com 0 quando não atende ao item analisado.

Os critérios adotados resultaram na Figura 14, que procura refletir a abrangência jurídica da legislação municipal. Não se está avaliando a pertinência ou eficiência da lei, ou ainda sua adequação à realidade social na qual está inserta.

Foram destacados em cinza escuro os municípios que obtiveram mais de $70 \%$ da pontuação; em cinza médio, os que apresentaram um resultado entre $50 \%$ e $70 \%$; e em cinza claro, os municípios que obtiveram menos que $43 \%$ da pontuação. Obteve-se, assim, o seguinte resultado:

(a) > 70\%: Americana, Holambra, Itatiba, Pedreira, Sumaré, Valinhos e Vinhedo;

(b) $>50 \%$ e < 70\%: Artur Nogueira, Campinas, Hortolândia, Jaguariúna e Nova Odessa;

(c) < 50\%: Cosmópolis, Indaiatuba, Monte Mor, Paulínia, Santa Barbara D’Oeste e Santo Antônio de Posse.

A partir dos resultados gerou-se a Figura 15, com o propósito de espacializar os dados no território metropolitano. 


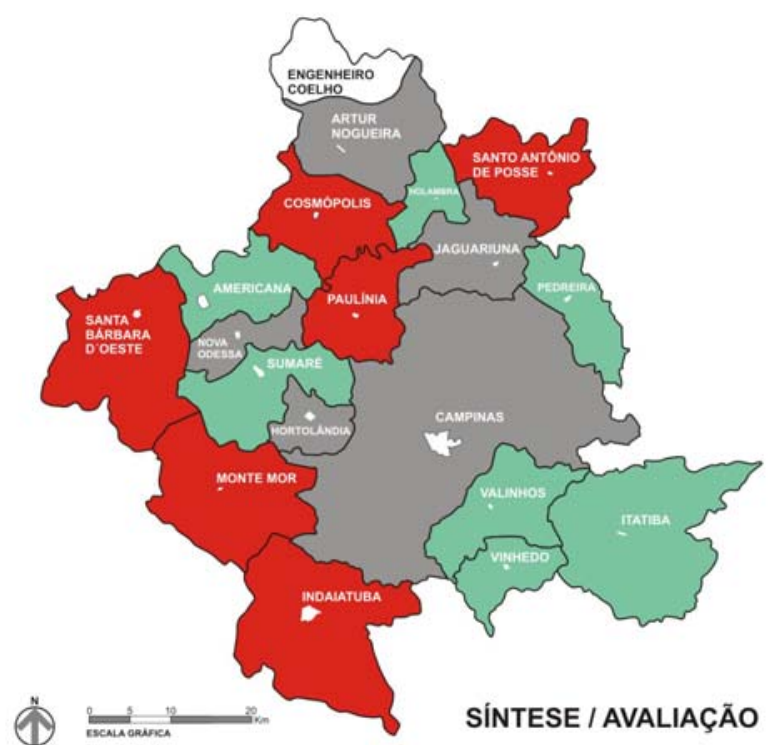

LEGENDA:

$\square$ RESPONDE A MAIS DE 70\% DAS QUESTÕES ABORDADAS RESPONDE DE $50 \%$ a $70 \%$ DAS QUESTÕES ABORDADAS RESPONDE A MENOS DE 50\% DAS QUESTŐES ABORDADAS

Figura 15 - Abrangência jurídica da legislação dos municípios da RMC

Segundo os critérios adotados, concluiu-se que aproximadamente $40 \%$ dos municípios estudados têm instrumentos legislativos de abrangência suficiente. Como já mencionado, a legislação não é suficiente para fazer cumprir a função social da propriedade, entretanto o quadro resultante indica a dificuldade encontrada por $60 \%$ dos municípios na incorporação do principio legal pelas legislações municipais.

\section{Referências}

ALFONSIN, B. Breve Estudo de Direito Urbanístico Comparado. In: DALLARI, A. A.; DI SARNO, D. C. L. Direito Urbanístico e

Ambiental. Rio de Janeiro: Lumen Juris, 2008. p. 147-182.

ARTUR NOGUEIRA. Lei Complementar $n^{\circ} 441$ de 03 de abril de 2007, que institui o Plano Diretor Participativo do Município de Artur Nogueira, nos termos do artigo 182 da Constituição Federal e do capítulo III da lei Federal no 10.257, de 10 de junho de 2001, e dá outras providências. Diário Oficial do Município, 08 de abril de 2007.

ARTUR NOGUEIRA. Lei Complementar $n^{\circ} 337$, de 08 de dezembro de 2003, que dispõe sobre o parcelamento, uso e ocupação do solo e empreendimetnos urbanísticos no município de Artur Nogueira e dá outras providências. Diário Oficial do Município, dezembro de 2003.

BRASIL. Constituição (1988). Emenda constitucional $n^{\circ}$ 9, de 9 de novembro de 1995. Lex: legislação federal e marginália, São Paulo, v. 59, p. 1966, out./dez. 1995.
BRASIL. Lei n. 10.257, de 10 de julho de 2001, que estabelece diretrizes gerais da política urbana. Brasília, Câmara dos Deputados, Coordenação de Publicações, 2001.

BRASIL. Lei n. 6.766, de 19 de dezembro de 1979, dispõe sobre o parcelamento do solo urbano e dá outras providências. Diário Oficial da União de 20 de dezembro de 1979.

BUENO, L. M. de M. Inovação para Concretização dos Direitos a Cidade: limites e possibilidades da lei e da gestão. In: BUENO, L. M. de M.; CYMALISTA, R. Planos diretores municipais: novo conceito do planejamento territorial. São Paulo, 2007.

CAMPINAS. Decreto $\mathrm{n}^{\circ} 16.390$, de 16 de Setembro de 2008, que cria o Grupo para Elaboração da Legislação Urbanística - GELU, regulamentadora da Lei Complementar 15/06 Plano Diretor do Município de Campinas e Legislação correlata. Diário Oficial do Município, 17 de setembro de 2008.

CAMPINAS. Lei Complementar $n^{\circ} 26$ de 03, de junho de 2009, que dispõe sobre o Plano Diretor do Município. Diário Oficial do Município, 04 de junho de 2009a.

CAMPINAS. Lei Complementar $n^{\circ} 28$ de 03 de setembro 2009, que dispõe sobre incentivos para a recuperação e conservação de imóveis de valor cultural, histórico e arquitetônico do Município de Campinas e disciplina o artigo 72 da Lei Complementar $n^{\circ} 15$, de 27 de dezembro de 2006, que dispõe sobre o Plano Diretor do Município de Campinas. Diário Oficial do Município, 04 de setembro de 2009b. 
CAMPINAS. Lei Complementar nº 004, de 17 de Janeiro de 1996, que dispõe sobre o Plano Diretor do Município de Campinas. Diário Oficial do Município, 18 de janeiro de 1996.

CAMPINAS. Lei Complementar $n^{\circ} 15$, de 27 de dezembro de 2006, que dispõe sobre o Plano Diretor do Município de Campinas. Diário Oficial do Município, 29 de dezembro de 2006.

CAMPINAS. Lei $n^{\circ} 11.621$, de 18 de julho de 2003, que dispõe sobre a concessão de uso especial para fins de moradia de imóveis públicos municipais. Diário Oficial do Município, 19 de setembro de 2003.

CHAUI, M. de S. Escritos Sobre a Universidade: Marilena Chaui. São Paulo: Unesp, 2001.

COELHO, R. T. Espaços Livres: sistema e projeto territorial. Rio de Janeiro: 7Letras, 2008.

COSMÓPOLIS. Lei Complementar n 2.949, de 03 de janeiro de 2007, que institui o Plano Diretor do Município de Cosmópolis e dá outras providências. Diário Oficial do Município, janeiro de 2007.

COSMÓPOLIS. Lei n 2.812, de 23 de maio de 2005, que dispõe sobre o uso e ocupação do solo e dá outras providências. Diário Oficial do Município, maio de 2005.

COSMÓPOLIS. Lei Complementar n 3.129, de 09 de junho de 2009, que altera dispositivos da lei complementar n. 2.949, de 03 de janeiro de 2007, que institui o Plano Diretor do Município de Cosmópolis e dá outras providências. Diário Oficial do Município, junho de 2009.

DAWKIN, J. Specification For a Metropolitan Planning Agency Which Can Make a Big Difference. In: ISOCARP CONGRESS, 46., Kenya, 2010. Anais... Kenya, 2010.

ENGELKE, D.; JURI, J. Urban-Regional Trialogue on Regional Land Use Management. In: ISOCARP CONGRESS, 43., Antuerpia, 2007. Anais... Antuerpia, 2007.

FORMAN, R. Land Mosaics: the ecology of landscape and regions. Cambridge: Cambridge University Press, 1997.

GILBERT, R.; STEVENSON, D. Governance and Economic Development: the regions of Toronto, Vancouver and Montreal. In: OECD. Cities for Citizens: improving metropolitan governance. Paris: Organization for Economic Co-Operation and Development, 2001. p. 199-241.

HALL, S. Da Diáspora: identidades e mediações culturais. Belo Horizonte: UFMG, 2006. Coleção Humanitas.
HARVEY, D. A Produção Capitalista do Espaço. São Paulo: Annablume, 2005.

HOLAMBRA. Anteprojeto de Lei Complementar do Plano Diretor de Holambra, maio de 2006.

HOLAMBRA. Anteprojeto de Lei Complementar do Plano Diretor de Holambra, dezembro de 2008.

HORTOLÂNDIA. Lei n ${ }^{0} 1.905$, de 21 de julho de 2007, que dispõe sobre empreendimentos habitacionais de interesse social e estabelece normas sobre habitação popular no município de hortolândia. Diário Oficial do Município, julho de 2007a.

HORTOLÂNDIA. Lei n ${ }^{\circ} 2.092$, de 04 de julho de 2008, que dispõe sobre o plano diretor do município de hortolândia. Diário Oficial do Município, julho de 2008.

HORTOLÂNDIA. Projeto de Lei no 160, de 2006, que autoriza a desafetação de áreas de terra de propriedade do Município, conforme especifica.

HORTOLÂNDIA. Projeto de Lei no 137, de 31 outubro de 2007, que dispõe do município de Hortolândia. Diário Oficial do Município, outubro de 2007b.

HORTOLÂNDIA. Plano Habitacional de Interesse Social. Hortolândia: Prefeitura Municipal de Hortolândia, 2005.

INDAIATUBA. Lei $n^{\circ} 4.067$, de 24 de setembro de 2001, que dispõe sobre a instituição do Plano Diretor do Município de Indaiatuba - PDI e dá outras providências. Diário Oficial do Município, 25 de setembro de 2001a.

INDAIATUBA. Lei $\mathrm{n}^{\circ} 4.594$ de 06 de outubro de 2004, que altera os perímetros previstos nos Anexos da Lei ${ }^{\circ} 4.067$, de 24 de setembro de 2001, que dispõe sobre a instituição do Plano Diretor do Município de Indaiatuba - PDI e dá outras providências. Diário Oficial do Município, 07 de outubro de 2004.

INDAIATUBA. Lei $n^{\circ}$ 4.066, de 24 de setembro de 2001, que dispõe sobre o ordenamento do uso e da ocupação do solo do Município de Indaiatuba e dá outras providências. Diário Oficial do

Município, 25 de setembro de 2001b.

INDAIATUBA. Lei $n^{\circ}$ 3.525, de 18 de março de 1998, que dispõe sobre loteamentos, arruamentos, retalhamentos de imóveis em geral, e dá outras providências. Diário Oficial do Município, 19 de março de 1998.

ITATIBA. Lei n ${ }^{\circ}$ 3.759, de 09 de setembro de 2004, que dispõe sobre o Plano Diretor do Município de Itatiba, que ordena o território e as políticas setoriais, e dá outras providências. Diário Oficial do Município, 10 de setembro de 2004a. 
ITATIBA. Lei ${ }^{\circ} 3.761$, de 14 de setembro de 2004, que dispõe sobre o parcelamento do solo e outras alternativas de urbanização para o território do Município de Itatiba e dá outras providências.

Diário Oficial do Município, 15 de setembro de 2004b.

ITATIBA. Lei $\mathrm{n}^{0}$ 3.765, de 22 de setembro de 2004, que dispõe sobre o uso e a ocupação do solo no território do Município de Itatiba e dá outras providências. Diário Oficial do Município, 23 de setembro de 2004c.

JAGUARIUNA. Lei $n^{\circ}$ 96, de 20 de dezembro de 2004, que dispõe sobre a instituição do Plano Diretor do Município de Jaguariúna-PDJ, e dá outras providências. Diário Oficial do Município, 21 de dezembro de 2004a.

JAGUARIUNA. Lei $n^{\circ}$ 97, de 20 de dezembro de 2004, que dispõe sobre o parcelamento e o ordenamento do uso e da ocupação do solo do Município de Jaguariúna, e dá outras providências. Diário Oficial do Município, 21 de dezembro de 2004b.

JAGUARIUNA. Lei n ${ }^{\circ} 126$, de 16 de julho de 2007, que substitui os Anexos II e III, da Lei Complementar $n^{\circ}$ 96/2004, que dispõe sobre instituição do Plano Diretor do Município de Jaguariúna - PDJ, e dá outras providências. Diário Oficial do Município, 17 de julho de 2007.

\section{LEFEBVRE, H. A Revolução Urbana. Belo} Horizonte: UFMG, 1999.

MAGNOLI, M. M. Espaço Livre: objeto de trabalho. Paisagem e Ambiente, São Paulo, n. 21, p. 177-200, 2006.

MARICATO, E. Brasil, Cidades: alternativas para a crise urbana. Petrópolis: Vozes, 2001a.

MARICATO, E. Limitações ao Planejamento Urbano Democrático. In: FREITAS, J. C. (Coord.). Temas de Direito Urbanístico 3. São Paulo: Ministério Público/Imprensa Oficial, 2001b.

\section{MARICATO, E. Metrópole na Periferia do Capitalismo: ilegalidade, desigualdade e violência. São Paulo: Hucitec, 1996.}

MONTE MOR. Lei $\mathrm{n}^{\circ} 0001$ de 07 junho de 2006, que dispõe sobre o Plano Diretor do Município de Monte Mor e dá outras providências. Diário

Oficial do Município, 08 de junho de 2006a.

MONTE MOR. Lei ${ }^{\circ} 0002$ de 07 junho de 2006, que dispõe sobre o uso, ocupação e parcelamento do solo no Município de Monte Mor e dá outras providências. Diário Oficial do Município, 08 de junho de 2006b.
MONTE MOR. Lei n. ${ }^{\circ} 11$ de 19 de dezembro de 2007, que altera os dispositivos da Lei Complementar $n^{\circ}$ 0002/06, de uso, ocupação e parcelamento do solo urbano e dá outras providências. Diário Oficial do Município, 20 de dezembro de 2007.

NOVA ODESSA. Lei no 10, de 06 de outubro de 2006, que institui o Plano Diretor Participativo e o Sistema de Planejamento Integrado e Gestão Participativa do Município de Nova Odessa, nos termos do Artigo 182 da Constituição Federal, do capítulo III da Lei ${ }^{\circ} 10.257$, de 10 de julho de 2001 - Estatuto da Cidade - e da Lei Orgânica do Município de Nova Odessa. Diário Oficial do Município, 07 de outubro de 2006.

NOVA ODESSA. Lei n ${ }^{\circ}$ 0674, de 30 de junho de 1978, mais infos

OMWENGA, M. Nairobi: emerging metropolitan region, development planning and management opportunities and challenge. In: ISOCARP CONGRESS, 46., Kenya, 2010. Anais... Kenya, 2010.

PAULÍNIA. Lei $\mathrm{n}^{\circ}$ 2.852, de 22 de dezembro de 2006, que institui o plano diretor do município de paulínia. Diário Oficial do Município, 23 de dezembro de 2006.

PAULÍNIA. Lei $n^{\circ}$ 39, de 24 de dezembro de 2008, que dispõe sobre o parcelamento, uso e ocupação do solo no município de paulínia, e dá outras providências. Diário Oficial do Município, 26 de dezembro de 2008.

PAULÍNIA. Lei ${ }^{\circ}$ 2.668, de 18 de dezembro de 2003, que dispõe sobre loteamentos urbanos, loteamentos fechados e condomínios fechados no município de paulínia e dá outras providências.

Diário Oficial do Município, 19 de dezembro de 2003.

PAULÍNIA. Decreto n ${ }^{\circ} 5.541$, de 25 de junho de 2007, que regulamenta a lei $\mathrm{n}^{\circ} 2.668$, de 18 de dezembro de 2003, que dispõe sobre loteamentos urbanos, loteamentos fechados e condomínios fechados no município de Paulínia e dá outras provicências. Diário Oficial do Município, 26 de junho de 2007.

PEDREIRA. Lei $n^{\circ} 2.792$, de 25 de março de 2008, que institui o novo plano diretor do Município de Pedreira, nos termos do artigo 182, da Constituição Federal, do capítulo III, da Lei ${ }^{\circ}$ 10.257, de 10 de julho de 2001 - Estatuto da Cidade. Diário Oficial do Município, 26 de março de 2008. 
QUEIROGA, E.; BENFATTI, D. Entre o Nó e a Rede, Dialéticas Espaciais Contemporâneas: o caso da metrópole de Campinas, diante da megalópole do Sudeste do Brasil. Revista Brasileira de Estudos Urbanos e Regionais, Rio de Janeiro, v. 9, n.1, p. 29-44, maio 2007.

RÊGO, A. Q. et al. O Sistema de Espaços Livres do Estado do Rio de Janeiro Projetado nos Planos Diretores Municipais: fronteiras políticoadministrativas modelando a paisagem territorial. In: ENCONTRO NACIONAL DE PAISAGISMO EM ESCOLAS DE ARQUITETURA, Curitiba, 2008. Anais... Curitiba, 2008.

ROLNIK, R. A Cidade e a Lei: legislação, política urbana e territórios na cidade de São Paulo. São Paulo: FAPESP/Studio Nobel, 1997.

SANTA BARBARA D’OESTE. Lei n ${ }^{\circ}$ 028, de 08 de novembro de 2006, que institui o Plano Diretor de Desenvolvimento do Município de Santa Bárbara d'Oeste e dá outras providências. Diário Oficial do Município, 09 de novembro de 2006.

SANTO ANTÔNIO DE POSSE. Lei n ${ }^{\circ}$ 017, de 11 de outubro de 2006, que dispõe sobre o Plano Diretor de Desenvolvimento Integrado do Município de Santo Antônio de Posse, e dá outras providências. Diário Oficial do Município, 12 de outubro de 2006.

SANTOS, M. A Urbanização Brasileira. São Paulo: Hucitec, 1993.

SÃO PAULO. Americana. Secretaria de Habitação e Desenvolvimento Urbano. Plano de Habitação de Americana: diagnóstico habitacional do município de Americana. Contrato Administrativo $n^{\circ}$ 231/08, Produto 2, out. 2002.

SÃO PAULO. Lei Complementar no 870, de 19 de junho de 2000 de São Paulo. Diário Oficial do Estado, 20 de junho 2000.

SÃO PAULO. Lei Municipal n. 4.597, de $1^{\circ}$ de fevereiro de 2008, que dispõe sobre o plano diretor de desenvolvimento integrado do município de Americana/PDDI. Diário Oficial do Estado, 2 de fevereiro 2008a.

SÃO PAULO. Lei Municipal n. 4.676, de 15 de julho de 2008, que dispõe sobre o parcelamento, a unificação, a modificação e o aproveitamento do solo para fins urbanos no território do Município e dá outras providências. Diário Oficial do Estado, 16 de julho de 2008b.

SCHWARZ, R. Cultura e Política. 2 ed. São Paulo: Terra e Paz, 2005.
SILVA, J. M. P. da. O Planejamento Participativo e a Transformação da Paisagem: planos diretores em onze municípios do Espírito Santo, um estudo de caso. In: TÂNGARI, V. et al. (Org.). Águas Urbanas: uma contribuição para a regeneração ambiental como campo disciplinar integrado. Rio de Janeiro: FAU/UFRJ-PROARQ, 2007. p. 173214.

SILVA, J. A. da. Direito Urbanístico Brasileiro. 5. ed. São Paulo: Malheiros, 2008.

SUMARÉ. Lei ${ }^{\circ}$ 4.250, de 06 de outubro de 2006, que dispõe sobre o Plano Diretor. Diário Oficial do Município, 07 de outubro de 2006.

SUMARÉ. Lei no 2.831, de 26 de dezembro de 1995, que dispõe sobre o parcelamento, uso e ocupação do solo do Município de Sumaré e dá outras providências. Diário Oficial do Município, 07 de outubro de 1995.

SUMARÉ. Lei no 4.759, de 24 de dezembro de 2008, que institui a Zona Especial de Interesse Social (ZEIS) no Jardim Nossa Senhora da Conceição II para fins de regularização urbanística. Diário Oficial do Município, 26 de dezembro de 2008a.

SUMARÉ. Lei no 4.760, de 24 de dezembro de 2008, que institui a Zona Especial de Interesse Social (ZEIS) no Jardim Irmã Davina para fins de regularização urbanística. Diário Oficial do Município, 26 de dezembro de 2008b.

SUMARÉ. Lei ${ }^{\circ} 4.880$, de 15 de outubro de 2009, que dispõe sobre Empreendimentos Habitacionais de Interesse Social - EHIS - e dá outras providências. Diário Oficial do Município, 16 de outubro de 2009.

VALINHOS. Lei $\mathrm{n}^{\circ}$ 3.841, de 21 de dezembro de 2004, que dispõe sobre o Plano Diretor III do Município de Valinhos e dá outras providências. Diário Oficial do Município, 22 de dezembro de 2004.

VALINHOS. Lei $n^{\circ} 4.186$, de 10 de outubro de 2007, que dispõe sobre a ordenação do uso e ocupação do solo no Município e dá outras providências. Diário Oficial do Município, 11 de outubro de 2007.

VILLAÇA, F. As Ilusões do Plano Diretor. São Paulo: Edição do autor, 2005.

VILLAÇA, F. Espaço Intra-Urbano no Brasil. São Paulo: Nobel; Fapesp, 1998.

VINHEDO. Lei $n^{\circ}$ 66, de 17 de janeiro de 2007, que dispõe sobre plano diretor participativo de vinhedo - PDPV, e dá outras providências. Diário Oficial do Município, 18 de janeiro de 2007. 
WANDERVAL, B. et al. Projeto de Lei n ${ }^{\circ} 3.057$, de 2000. Disponível em:

$<$ http://www.camara.gov.br/sileg/integras/516752. pdf $>$. Acesso em: 14 set. 2011.

Revista Ambiente Construído

Associação Nacional de Tecnologia do Ambiente Construído

Av. Osvaldo Aranha, 99 - 3o andar, Centro

Porto Alegre - RS - Brasil

CEP 90035-190

Telefone: +55 (51) 3308-4084

Fax: +55 (51) 3308-4054

www. seer. ufrgs. br/ ambienteconstruido

E-mail: ambienteconstruido@ufrgs.br 